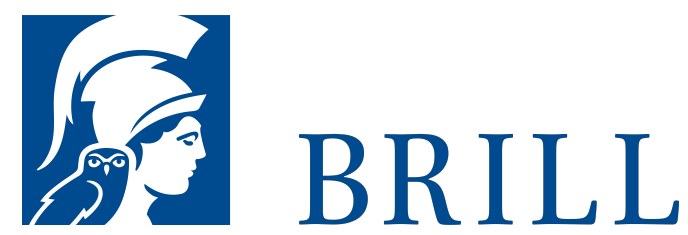

\title{
Rembrandts Rauheit
}

Eine phänomenologische Untersuchung

Author: Nicola Suthor

Die Rembrandt kennzeichnende Materialität des Farbauftrags wird in der Ausdeutung des Bildsujets gern übersehen bzw. als Indiz von Unvollendetheit gewertet. Die visuelle Kraft seiner rauen Malerei ist jedoch, wie Nicola Suthor im Einzelnen zeigt, äußerst subtil und kreiert eine vielschichtige, sinnbildende Textur, die einen Subtext eröffnet und Ausdruckstiefe herstellt. Die stets gelobte Beseeltheit des Dargestellten ist von der Rauheit der Darstellung nicht zu trennen. Edmund Husserls Differenzierung des Bildes in drei Aspekte und Maurice Merleau-Pontys Begriffe des indirekten Sprechens und des Fleischs dienen als Instrumentarium, die Wirkungsweisen insbesondere »verschmierter« Passagen präziser zu analysieren. Auch Rembrandts Helldunkel, die Sichtbarkeit des Malgrunds und die Setzung der Farbe Rot als Farbblock weisen intentionale Strukturen auf, die an der phänomenalen Wucht des jeweiligen Bilds entscheidend mitwirken.

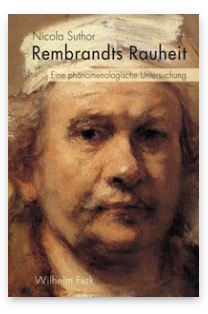

Pages: 220

Seiten, $39 \mathrm{~s} / \mathrm{w}$ und 16 farb. Abb.

Language:

German

Subjects: Art

History, Art

History

Publisher: Brill | Fink

E-Book (PDF)

Released online:

29 Jan 2020

ISBN: $978-3-$

8467-5739-0

List price

Paperback

Publication date:

17 Nov 2014

ISBN: 978-3-

7705-5739-4

List price 
For more information see brill.com

Order information: Order online at brill.com +44330 333 0049 | customerservices@brill.com Submission information: brill.com/authors

Titles published by Brill | Fink, Brill | mentis or Brill | Schöningh: +49(o)715413279216| brill@brocom.de 